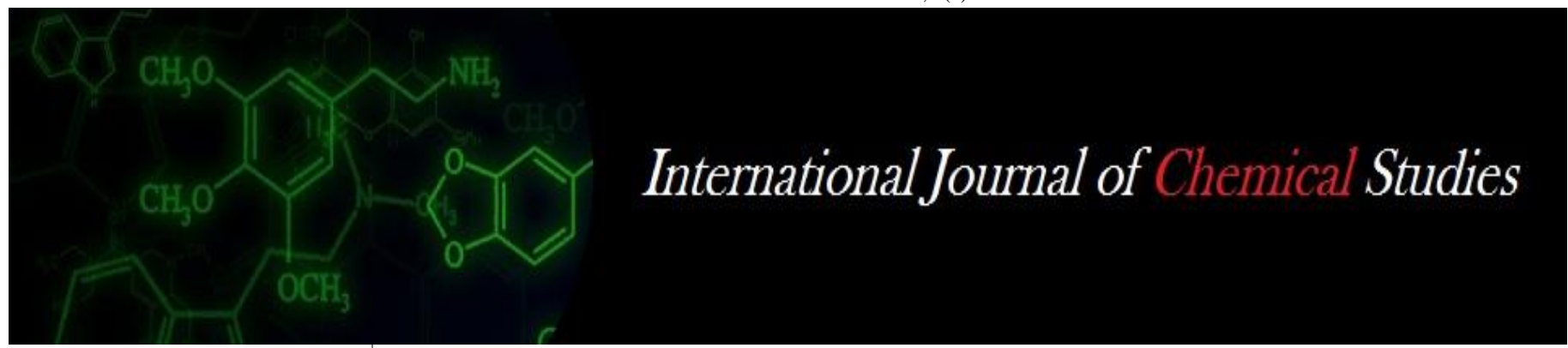

P-ISSN: 2349-8528

E-ISSN: 2321-4902

www.chemijournal.com

IJCS 2020; 8(5): 416-419

(C) 2020 IJCS

Received: 22-07-2020

Accepted: 24-08-2020

\section{N Ramanaji}

B. A. College of Agriculture,

Anand Agricultural University,

Anand, Gujarat, India

\section{Dabhi}

Sheth M. C. Polytechnic in Agriculture, Anand Agricultural University, Anand, Gujarat, India

\section{AD Kalola}

B. A. College of Agriculture, Anand Agricultural University, Anand, Gujarat, India
Corresponding Author: MV Dabhi

Sheth M. C. Polytechnic in Agriculture, Anand Agricultural University, Anand, Gujarat, India

\section{Management of rice moth, Corcyra cephalonica (Stainton) by using non-toxic plant powders in stored groundnut seeds}

\author{
N Ramanaji, MV Dabhi and AD Kalola
}

DOI: https://doi.org/10.22271/chemi.2020.v8.i5f.10329

\begin{abstract}
Laboratory experiment was conducted to study the efficacy of botanical powders viz., neem leaf powder, lantana leaf powder, custard apple leaf powder, eucalyptus leaf powder, marigold flower powder, turmeric rhizome powder, neem seed kernel powder, ginger rhizome powder, and garlic bulb powder @ $2.5 \mathrm{~g} / 100 \mathrm{~g}$ kernels in protecting stored groundnuts against rice moth. Neem seed kernel powder was found to be most effective in protecting stored groundnuts against rice moth as it recorded highest oviposition deterrence of $92.16 \%$, maximum reduction of adult emergence of $95.89 \%$, lowest longevity of male ( 2.85 days) and female ( 2.89 days) moths, lowest fecundity of 42.80 eggs per female and lowest egg viability of $43.96 \%$. Next effective treatments were neem leaf powder and eucalyptus leaf powder @ $2.5 \mathrm{~g} / 100 \mathrm{~g}$ kernels. None of the plant powders had hindered the germination of groundnut seeds during storage periods of up to 120 days.
\end{abstract}

Keywords: Egg viability, fecundity, groundnut, longevity, rice moth

\section{Introduction}

Groundnut, Arachis hypogea Linnaeus is an important legume crop that is widely cultivated in the tropics and subtropics. It is also known for its high-oil edible seeds and is therefore the fourth largest source of edible oil in the world. It is also well known for its high protein level. (Anonymous, 2018) ${ }^{[2]}$. More than 100 species of insects infesting stored groundnuts are documented (Delinger and Davis, 1982) ${ }^{[5]}$. Rice moth, Corcyra cephalonica (Stainton) is considered to be a major pest of stored groundnut (Menge et al., 2018) ${ }^{[12]}$. The damaging stage of this pest is larva which attacks groundnut, rice, wheat, maize, sorghum, cotton seeds, coffee, spices, chocolate, dried fruit, biscuits and seeds under various storage conditions. While feeding on the grains they spin dense silk tubes and weave the grain kernels into the walls of the tubes (Atwal and Dhaliwal, 2008) ${ }^{[3]}$. About 6 to $10 \%$ of the groundnut kernels are destroyed by insect pests in bags (FAO, 2002) ${ }^{[7]}$. Immense post-harvest losses and deterioration in quality caused by storage pests are a serious problem facing agriculture in developing countries. The use of fumigants is the most economical tool for the management of stored grain pests; however, storage pests are rapidly developing resistance to phosphine (Suleiman and Yusuf, 2011) ${ }^{[16]}$. Pesticide use is harmful to farmers and consumers because of their residual problems (Menge et al., 2018) ${ }^{[12]}$. Unlike chemical insecticides, plant-based products are environmentally sustainable, economically viable, have least adverse effect on seed germination, are non-toxic to mammals and are readily available (Jhala et al., 2018) ${ }^{[8]}$. Hence, keeping the view of above facts the present experiment was undertaken to evaluate the plant powders against $C$. cephalonica in stored groundnut under laboratory conditions.

\section{Materials and Methods}

The experiment was conducted at Department of Entomology, B. A. College of Agriculture, AAU, Anand. To study the efficacy of nine plant powders viz., neem leaf powder, lantana leaf powder, custard apple leaf powder, eucalyptus leaf powder, marigold flower powder, turmeric rhizome powder, neem seed kernel powder, ginger rhizome powder, and garlic bulb powder@ $2.5 \mathrm{~g} / 100 \mathrm{~g}$ of kernels as seed protectant of groundnut against rice moth, for which a laboratory experiment was conducted. 
The groundnut seeds were sterilized properly in a hot air oven at $55{ }^{\circ} \mathrm{C}$ for a period of four hours and then the moisture content of the seeds was adjusted between 14 to 16 per cent by putting the seeds inside a desiccator at high humidity level after sterilization. Groundnut seeds were mixed with plant powders@2.5 g/100 g of kernels. These treated seeds were stored in plastic jars (diameter $10.0 \mathrm{~cm}$ and height $8.0 \mathrm{~cm}$ ). The mouth of the jars was covered with fine black muslin cloth tied with rubber bands. Each treatment was replicated thrice. All the jars were kept in the laboratory at room temperature.

\section{Oviposition deterrence $(\%)$}

For each treatment, $500 \mathrm{~g}$ seeds of groundnut were taken in a conical flask and mixed with plant powders while seeds without treatment were used as control. After proper mixing the seeds were separated into three lots each having $100 \mathrm{~g}$ seeds which were stored in plastic containers $(10 \times 8 \mathrm{~cm})$. Five pairs of newly emerged adults of rice moth were introduced in each container. The control was maintained separately for each repetition. After 3 days, number of eggs laid in treated seeds (Ts) and control seeds (Cs) were recorded and the oviposition deterrence (\%) was calculated by following formula given by Pradyuman Singh and Jakhmola $(2011)^{[13]}$.

$\mathrm{POD}=\frac{C_{s}-T_{s}}{C_{s}} \times 100$

Where,

$\mathrm{T}_{\mathrm{s}}=$ Number of eggs laid in treated seeds

$\mathrm{C}_{\mathrm{s}}=$ Number of eggs laid in control seeds

$\mathrm{POD}=$ Per cent oviposition deterrence

\section{Reduction in adult emergence $(\%)$}

The eggs were counted from each treatment. The experimental set was kept undisturbed till the emergence of $F_{1}$ adults from the treated and untreated seeds. The number of $F_{1}$ adults emerged from the control seeds (Ac) and treated seeds (At) was recorded. Reduction in adult emergence (\%) was calculated by the following formula given by Pradyuman Singh and Jakhmola (2011) ${ }^{[13]}$.

$\mathrm{PRA}=\frac{A_{c}-A_{t}}{A_{c}} \times 100$

Where,

$A_{c}=$ Number of $F_{1}$ adults emerged from the control seeds $A_{t}=$ Number of $F_{1}$ adults emerged from the treated seeds

$\mathrm{PRA}=$ Per cent reduction in adult emergence

\section{Longevity of male and female emerged}

Total number of male and female moths emerged from each treatment was recorded along with its longevity.

\section{Fecundity}

For recording the fecundity, ten freshly emerged adults from the larvae reared on treated food were kept in separate jars for egg laying. The total numbers of eggs laid by each female were counted daily till the death of female.

\section{Egg viability (\%)}

For egg viability, random samples of 50 eggs were taken from each treatment and placed in petri plates. The hatched or unhatched eggs were counted with the help of stereomicroscope.

\section{Germination (\%) of groundnut seeds}

Germination test was carried out using Whatman's filter paper No.1 sheets. The filter paper was placed horizontally in order to arrange seeds for germination. Fifty seeds were spread on germination paper at uniform distance. The seeds were covered with a wax paper, folded at one end and rolled properly leaving another end open in order to provide moisture for the germinating seeds. The seeds were kept in a seed germinator maintained at $21 \pm 1{ }^{\circ} \mathrm{C}$ temperature and $95 \pm$ 2 per cent relative humidity. Distilled water was sprinkled on filter paper once a day to keep it moist. The number of germinated seeds was counted after 7 days of incubation. Thus, germination test was carried out after 120 days of storage to see the effect of plant powders on germination of groundnut seeds. The data on per cent germination was subjected to ANOVA after transforming them to arc sin (Steel and Torrie, 1980) ${ }^{[15]}$.

\section{Results and Discussion}

Evaluation of plant powders on oviposition deterrence, reduction in adult emergence, longevity, sex ratio, fecundity and egg viability of rice moth and germination percentage of groundnut seeds which present in Table 1.

\section{Oviposition deterrence $(\%)$}

It was found that all the plant powders showed significant reduction in oviposition against rice moth damage. Maximum oviposition deterrence $(92.16 \%)$ was observed in neem seed kernel powder@ $2.5 \mathrm{~g} / 100 \mathrm{~g}$ of kernels followed by neem leaf powder $(88.29 \%)$, eucalyptus leaf powder $(83.97 \%)$ and garlic bulb powder $(79.47 \%) @ 2.5 \mathrm{~g} / 100 \mathrm{~g}$ of kernels which significantly differed from each other. Similar trend was also observed that maximum reduction in oviposition of rice moth observed when sorghum and groundnut seeds treated with karanj kernel powder and neem seed kernel powder, respectively (Meena and Bhargavam, 2005 and Dulera et al., 2015) ${ }^{[10,6]}$.

\section{Reduction in adult emergence (\%)}

The highest reduction in adult emergence was observed in neem seed kernel powder (95.89\%) @ $2.5 \mathrm{~g} / 100 \mathrm{~g}$ of kernels, which was significantly different from all other treatments. The next effective treatments were neem leaf powder (93.72\%), eucalyptus leaf powder $(90.61 \%)$ and garlic bulb powder $(87.01 \%)$ which were significantly different from each other. According to Senguttuvan et al. (1995) ${ }^{[14]}$ and Choudhary et al. (2017) ${ }^{[4]}$ that the neem leaf powder was the most toxic material followed by neem seed kernel powder in reducing the adult emergence of stored grain insect pests. Menge et al. (2018) ${ }^{[12]}$ also observed that neem seed kernel powder@6 g/100 g of groundnut kernels was found effective in reducing the adult emergence of rice moth.

\section{Longevity of male and female of $\boldsymbol{C}$. cephalonica}

Neem seed kernel powder @ $2.5 \mathrm{~g} / 100 \mathrm{~g}$ of kernels $(2.85$ days) was found to be the most effective in reducing the longevity of male moths. The next effective treatments were neem leaf powder (3.46 days) and eucalyptus (leaf) powder (4.08 days). The female longevity on treatment with neem seed kernel powder (2.89 days) was superior over all other treatments. It was followed by neem leaf powder (3.54 days) and eucalyptus leaf powder (3.58 days) which were 
statistically at par with each other. Meena and Bhargavam (2005) ${ }^{[10]}$ observed that neem seed kernel powder and dharek kernel powder were most effective in reducing the longevity of adults of rice moth. The similar observation also reported by Meena et al. (2016) ${ }^{[11]}$ on rice moth and Choudhary et al. (2017) ${ }^{[4]}$ on pulse beetle.

\section{Sex ratio}

Sex ratio (Male: Female) of $C$. cephalonica was calculated from the adults emerged under laboratory conditions. The sex-ratios $(\hat{\delta}$ : + ) of $C$. cephalonica ranged from 1:1 lantana (leaf) powder to 1: 1.13 neem (seed kernel) powder. So, the female had slight preponderance over the male. A more or less similar result was also recorded by Allotey and Azalekor (1999) ${ }^{[1]}$, who showed the sex-ratios of $1: 1$ on $C$. cephalonica.

\section{Fecundity}

All the plant powders were found to be effective in reducing the fecundity of rice moth over control. Neem seed kernel powder@ $2.5 \mathrm{~g} / 100 \mathrm{~g}$ of kernels was most effective in reducing the fecundity and recorded $42.80 \mathrm{eggs} /$ female which was followed by neem leaf powder (48.36 eggs/female), eucalyptus leaf powder (58.48 eggs/female) and garlic bulb powder (69.39 eggs/female) which were significantly different from each other. Meena and Bhargavam (2005) ${ }^{[10]}$ found maximum reduction in fecundity was observed on seeds treated with karanj kernel powder (70.25\%) @ $5.0 \mathrm{~g}$ $/ 100 \mathrm{~g}$ seeds. The present findings also confirmed with past research work carried out by Dulera et al. (2015) ${ }^{[6]}$.

\section{Egg viability (\%)}

The results revealed that $94.68 \%$ of egg viability occurred in control. The minimum egg viability $(43.96 \%)$ was observed in groundnut kernels treated with neem seed kernel powder which was followed by neem leaf powder (48.62\%), eucalyptus leaf powder $(53.96 \%)$ and garlic bulb powder $(60.62 \%)$. Meena and Bhargavam (2003) ${ }^{[9]}$ found that kernel powder of neem, karanj and dharek were found to be the most effective. The present results support the past findings of Dulera et al. (2015) ${ }^{[6]}$, maximum reduction of egg viability was observed with karanj and neem seed kernel powder. Meena et al. (2016) [10] studied that maximum (55.16) reduction in egg viability was observed in dharak kernel powder@ $5 \mathrm{~g} / 100 \mathrm{~g}$ of kernels which was statistically at par with neem seed kernel powder @ $5 \mathrm{~g} / 100 \mathrm{~g}$ of kernels.

Table 1: Evaluation of plant powders on oviposition deterrence, reduction in adult emergence, longevity, sex ratio, fecundity \& egg viability of rice moth and germination percentage of groundnut seeds

\begin{tabular}{|c|c|c|c|c|c|c|c|c|c|}
\hline \multirow[t]{2}{*}{ Sr. No. } & \multirow[t]{2}{*}{ Treatments } & \multirow{2}{*}{$\begin{array}{c}* \text { Mean } \\
\text { Oviposition } \\
\text { deterrence }(\%)\end{array}$} & \multirow{2}{*}{$\begin{array}{c}\text { *Mean Reduction } \\
\text { in adult emergence } \\
(\%)\end{array}$} & \multicolumn{2}{|c|}{$\begin{array}{l}* * \text { Longevity } \\
\text { (Days) }\end{array}$} & \multirow{2}{*}{$\begin{array}{c}\text { Sex } \\
\text { ratio } \\
\delta: 0\end{array}$} & \multirow[t]{2}{*}{$* *$ Fecundity } & \multirow{2}{*}{\begin{tabular}{|c|} 
Egg \\
viability \\
$(\%)$
\end{tabular}} & \multirow{2}{*}{$\begin{array}{c}* \text { Germination } \\
(\%)\end{array}$} \\
\hline & & & & Male & Female & & & & \\
\hline 1 & $\begin{array}{c}\text { Neem leaf powder@ } 2.5 \\
\text { g/100 g seeds }\end{array}$ & $\begin{array}{l}69.99 b \\
(88.29)\end{array}$ & $\begin{array}{l}75.49 b \\
(93.72)\end{array}$ & $\begin{array}{l}1.99 \mathrm{e} \\
(3.46)\end{array}$ & $\begin{array}{c}2.01 \mathrm{f} \\
(3.54)\end{array}$ & $1: 1.03$ & $\begin{array}{c}6.99 \mathrm{~h} \\
(48.36)\end{array}$ & $\begin{array}{c}44.21 \mathrm{f} \\
(48.62)\end{array}$ & $\begin{array}{c}67.02 \\
(84.76)\end{array}$ \\
\hline 2 & $\begin{array}{c}\text { Lantana leaf powder@ } 2.5 \\
\text { g/100 g seeds }\end{array}$ & $\begin{array}{r}47.24 \mathrm{i} \\
(53.91) \\
\end{array}$ & $\begin{array}{l}49.69 \mathrm{~g} \\
(58.15) \\
\end{array}$ & $\begin{array}{l}2.44 \mathrm{~b} \\
(5.45) \\
\end{array}$ & $\begin{array}{l}2.51 \mathrm{~b} \\
(5.80) \\
\end{array}$ & $1: 1.00$ & $\begin{array}{l}10.16 \mathrm{~b} \\
(102.73) \\
\end{array}$ & $\begin{array}{l}64.95 \mathrm{~b} \\
(82.07) \\
\end{array}$ & $\begin{array}{c}64.45 \\
(81.40) \\
\end{array}$ \\
\hline 3 & $\begin{array}{c}\text { Custard apple leaf powder@ } \\
2.5 \mathrm{~g} / 100 \mathrm{~g} \text { seeds }\end{array}$ & $\begin{array}{l}50.49 \mathrm{~h} \\
(59.52)\end{array}$ & $\begin{array}{l}50.86 \mathrm{~g} \\
(60.16)\end{array}$ & $\begin{array}{l}2.37 \mathrm{bc} \\
(5.12)\end{array}$ & $\begin{array}{l}2.45 b c \\
(5.50)\end{array}$ & $1: 1.01$ & $\begin{array}{c}9.95 \mathrm{~b} \\
(98.50)\end{array}$ & $\begin{array}{l}63.89 \mathrm{~b} \\
(80.63)\end{array}$ & $\begin{array}{c}66.50 \\
(84.10)\end{array}$ \\
\hline 4 & \begin{tabular}{|c|}
$\begin{array}{c}\text { Eucalyptus leaf powder@ } 2.5 \\
\text { g/100 g seeds }\end{array}$ \\
\end{tabular} & $\begin{array}{l}66.40 \mathrm{c} \\
(83.97)\end{array}$ & $\begin{array}{l}72.16 \mathrm{c} \\
(90.61)\end{array}$ & $\begin{array}{l}2.14 \mathrm{~d} \\
(4.08)\end{array}$ & $\begin{array}{r}2.02 \mathrm{f} \\
(3.58)\end{array}$ & $1: 1.04$ & $\begin{array}{c}7.68 \mathrm{~g} \\
(58.48) \\
\end{array}$ & $\begin{array}{l}47.27 \mathrm{e} \\
(53.96) \\
\end{array}$ & $\begin{array}{c}66.45 \\
(84.04) \\
\end{array}$ \\
\hline 5 & $\begin{array}{c}\text { Marigold flower powder@ } \\
2.5 \mathrm{~g} / 100 \mathrm{~g} \text { seeds }\end{array}$ & $\begin{array}{l}55.72 \mathrm{f} \\
(68.28)\end{array}$ & $\begin{array}{l}59.62 \mathrm{e} \\
(74.42)\end{array}$ & $\begin{array}{l}2.16 \mathrm{~d} \\
(4.17)\end{array}$ & $\begin{array}{l}2.22 \mathrm{de} \\
(4.43)\end{array}$ & $1: 1.01$ & $\begin{array}{l}8.94 d \\
(79.42)\end{array}$ & $\begin{array}{l}57.62 \mathrm{c} \\
(71.32)\end{array}$ & $\begin{array}{c}65.43 \\
(82.71)\end{array}$ \\
\hline 6 & $\begin{array}{c}\text { Turmeric rhizome powder@ } \\
2.5 \mathrm{~g} / 100 \mathrm{~g} \text { seeds }\end{array}$ & $\begin{array}{l}52.87 \mathrm{~g} \\
(63.56)\end{array}$ & $\begin{array}{l}54.86 f \\
(66.87)\end{array}$ & $\begin{array}{l}2.27 \mathrm{c} \\
(4.65)\end{array}$ & $\begin{array}{l}2.35 \mathrm{~cd} \\
(5.02)\end{array}$ & $1: 1.01$ & $\begin{array}{l}9.43 \mathrm{c} \\
(88.42)\end{array}$ & $\begin{array}{l}59.75 c \\
(74.62)\end{array}$ & $\begin{array}{c}63.92 \\
(80.67)\end{array}$ \\
\hline 7 & $\begin{array}{c}\text { Neem seed kernel powder@ } \\
2.5 \mathrm{~g} / 100 \mathrm{~g} \text { seeds }\end{array}$ & $\begin{array}{l}73.74 \mathrm{a} \\
(92.16)\end{array}$ & $\begin{array}{l}78.31 \mathrm{a} \\
(95.89)\end{array}$ & $\begin{array}{l}1.83 \mathrm{f} \\
(2.85)\end{array}$ & $\begin{array}{l}1.84 \mathrm{~g} \\
(2.89)\end{array}$ & $1: 1.13$ & $\begin{array}{c}6.58 \mathrm{i} \\
(42.80)\end{array}$ & $\begin{array}{l}41.53 \mathrm{~g} \\
(43.96)\end{array}$ & $\begin{array}{c}67.53 \\
(85.39)\end{array}$ \\
\hline 8 & $\begin{array}{c}\text { Ginger rhizome powder@ } 2.5 \\
\text { g/100 g seeds }\end{array}$ & $\begin{array}{l}58.19 \mathrm{e} \\
(72.22)\end{array}$ & $\begin{array}{l}61.30 \mathrm{e} \\
(76.94)\end{array}$ & $\begin{array}{l}2.32 \mathrm{c} \\
(4.88)\end{array}$ & $\begin{array}{l}2.17 \mathrm{e} \\
(4.21)\end{array}$ & $1: 1.01$ & $\begin{array}{c}8.68 \mathrm{e} \\
(74.84)\end{array}$ & $\begin{array}{l}53.11 \mathrm{~d} \\
(63.97)\end{array}$ & $\begin{array}{c}66.02 \\
(83.48)\end{array}$ \\
\hline 9 & $\begin{array}{c}\text { Garlic bulb powder@ } 2.5 \\
\text { g/100 g seeds }\end{array}$ & $\begin{array}{l}63.06 \mathrm{~d} \\
(79.47) \\
\end{array}$ & $\begin{array}{l}68.87 d \\
(87.01)\end{array}$ & $\begin{array}{l}2.27 \mathrm{c} \\
(4.65) \\
\end{array}$ & $\begin{array}{l}2.13 \mathrm{ef} \\
(4.04)\end{array}$ & $1: 1.01$ & $\begin{array}{c}8.36 \mathrm{f} \\
(69.39) \\
\end{array}$ & \begin{tabular}{|l|}
$51.13 \mathrm{~d}$ \\
$(60.62)$ \\
\end{tabular} & $\begin{array}{c}64.45 \\
(81.40) \\
\end{array}$ \\
\hline 10 & Control & $\begin{array}{l}05.22 \mathrm{j} \\
(00.83)\end{array}$ & $\begin{array}{l}05.22 \mathrm{~h} \\
(00.83)\end{array}$ & $\begin{array}{l}3.01 \mathrm{a} \\
(8.56)\end{array}$ & $\begin{array}{l}3.04 \mathrm{a} \\
(8.74)\end{array}$ & $1: 1.03$ & $\begin{array}{l}14.70 \mathrm{a} \\
(215.59)\end{array}$ & \begin{tabular}{|c|}
$76.67 \mathrm{a}$ \\
$(94.68)$ \\
\end{tabular} & $\begin{array}{c}68.06 \\
(86.04)\end{array}$ \\
\hline & $\begin{array}{l}\text { S. Em. } \pm \\
\text { C.D (at } 5 \%) \\
\text { C.V. } \%\end{array}$ & $\begin{array}{l}0.57 \\
\text { Sig. } \\
1.85\end{array}$ & $\begin{array}{l}0.61 \\
\text { Sig. } \\
1.86\end{array}$ & $\begin{array}{l}0.04 \\
\text { Sig. } \\
3.19\end{array}$ & $\begin{array}{l}0.03 \\
\text { Sig. } \\
2.36\end{array}$ & & $\begin{array}{l}0.07 \\
\text { Sig. } \\
1.43\end{array}$ & $\begin{array}{l}0.84 \\
\text { Sig. } \\
2.61\end{array}$ & $\begin{array}{l}1.24 \\
\mathrm{NS} \\
3.26\end{array}$ \\
\hline
\end{tabular}

Note:

1. Figures in parentheses are retransformed values, whereas figures outside the parentheses indicate *angular transformed values and $* *$ square root transformed values.

2. Treatment mean(s) with letter(s) in common are non-significant by DNMRT at $5 \%$ level.

\section{References}

1. Allotey J, Azalekor W. Some aspects of the biology and control using botanicals of the rice moth, Corcyra cephalonica (Stainton), on some pulses. Journal of Stored Products Research. 1999; 36(3):235-243.

2. Anonymous

https://apeda.gov.in/apedawebsite/Announcements/2018 groundnut survey report.pdf, 2018.
3. Atwal AS, Dhaliwal GS. Agricultural pests of south Asia and their management, Kalyani publishers, Ludhiana, Punjab 2008, 155-158.

4. Choudhary S, Bhargva M, Samota R. Eco-friendly management of pulse beetle Callosobruchus chinensis using plant powder on stored lentil. Trends in Biosciences. 2017; 10(12):2241-2245.

5. Delinger LM, Davis R. Insect control in postharvest peanuts: Peanut science and technology. American peanut research and education society. 1982, 521-570. 
6. Dulera JG, Jethva DM, Khanpara AV, Sandpa MB. Effectiveness of plant powders on reproductive potential of Corcyra cephalonica on stored groundnut. Journal of Experimental Zoology. 2015; 18(1):483-488.

7. FAO Post-harvest compendium: Groundnut post harvest operations. FAO, Geneva, Switzerland, 2002.

8. Jhala J, Vyas A, Swami H, Mordia A. Efficacy of different plant products against rice moth (Corcyra cephalonica, Stainton) in rice. Journal of Entomology and Zoology Studies. 2018; 6(4):1109-1112.

9. Meena BL, Bhargavam MC. Effect of plant products on reproductive potential of Corcyra cephalonica Stainton (Lepidoptera: Pyralidae). Annals of plant protection sciences. 2003; 11(2):196-200.

10. Meena BL, Bhargavam MC. Effect of different plant powders on the reproductive potential of rice moth, Corcyra cephalonica Stainton. Agricultural Science Digest. 2005; 25(2):103-106.

11. Meena BL, Jeengar KL, Singh B, Meena NL. Evaluation of different plant powders as seed protectants against rice moth, Corcyra cephalonica (Stainton). Journal of Applied and Natural Science. 2016; 8(2):910-918.

12. Menge AK, Naik KV, Golvankar GM. Evaluate of plant products against Corcyra cephalonica (Stainton) in stored groundnut kernel. International Journal of Chemical Studies. 2018; 6(5):2936-2941.

13. Pradyuman Singh, Jakhmol SS. Efficacy of botanical extracts on biological activities of pulse beetle Callosobruchus maculatus (Fab.) on green gram. Trends in biosciences. 2011; 4(1):25-30.

14. Senguttuvan T, Kareem AA, Rajendran R. Effects of plant products and edible oils against rice moth Corcyra cephalonica (Stainton) in stored groundnuts. Journal of Stored Products Research. 1995; 31(3):207-210.

15. Steel RGD, Torrie JH. Principles and procedures of statistics. Publisher McGraw-Hill Book Company, New York, 1980, 334.

16. Suleiman M, Yusuf MA. The potential of some plant powders as biopesticides against Sitophilus zeamais (Coleoptera: Curculionidae) and Callosobruchus maculatus (Coleoptera: Bruchidae) On Stored Grains: Bayero Journal of Pure and Applied Sciences. 2011; 4:204-207. 